\section{IMPLEMENTASI UNDANG-UNDANG NOMOR 19 TAHUN 2016 TENTANG PERUBAHAN ATAS UNDANG-UNDANG NOMOR 11 TAHUN 2008 TENTANG ITE TERHADAP KEBEBASAN BERPENDAPAT DI INDONESIA ${ }^{1}$ Oleh: Yosua Julio Lalujan ${ }^{2}$ Liju Zet Viany ${ }^{3}$}

\begin{abstract}
ABSTRAK
Tujuan dilakukannya penelitian ini adalah untuk mengetahui bagaimana Perlindungan atas kebebasan berpendapat dalam Undang-undang No 19 Tahun 2016 Tentang Perubahan Atas Undang-undang No 11 Tahun 2008 Tentang ITE dan mengapa Undang-undang No 19 Tahun 2016 Tentang Perubahan Atas Undang-undang No 11 Tahun 2008 Tentang ITE mengancam kebebasan berpendapat $\mathrm{Di}$ Indonesia, yang dengan metode penelitian hukum normatif disimpulkan: 1. Kebebasan berpendapat dalam Undang-Undang No. 19 Tahun 2016 tentang perubahan atas undang-undang no 11 tahun 2008 tentang Informasi dan Transaksi Elektronik (ITE) belum di atur dengan baik. 2 . Pasal 27 Undang-Undang No. 19 Tahun 2016 tentang perubahan atas undang-undang no 11 tahun 2008 tentang Informasi dan Transaksi Elektronik (ITE) dapat mengancam kebebasan berpendapat karena pasal tersebut multitafsir. Kata kunci: kebebasan berpendapat; informasi dan transaksi elektronik;
\end{abstract}

\section{PENDAHULUAN \\ Latar Belakang}

Pemerintah lewat Undang Undang No 19 Tahun 2016 Tentang Perubahan Atas Undang Undang no 11 Tahun 2008 Tentang ITE khususnya dalam pasal 27 mengatur tentang illegal content, Perbuatan yang di larang dalam menyampaikan atau mendistribusikan pendapat, karena kebebasan berpendapat bukanlah kebebasan sebebas-bebasnya melainkan masih ada batasan, yang batas tersebut di tetapkan di dalam Undang Undang, agar supaya untuk menjamin pengakuan serta penghormatan atas hak kebebasan orang lain, dan untuk memenuhi tuntutan yang adil sesuai dengan pertimbangan moral, nilai nilai agama , keamanan, dan ketertiban umum dan juga memberikan rasa aman, keadilan, dan kepastian hukum bagi pengguna dan Penyelenggara sistem electronik ${ }^{4}$.

\section{Rumusan Masalah}

1. Bagaimana Perlindungan atas kebebasan berpendapat dalam Undang-undang No 19 Tahun 2016 Tentang Perubahan Atas Undang-undang No 11 Tahun 2008 Tentang ITE ?

2. Mengapa Undang-undang No 19 Tahun 2016 Tentang Perubahan Atas Undangundang No 11 Tahun 2008 Tentang ITE mengancam kebebasan berpendapat Di Indonesia?

\section{Metode Penelitian}

Jenis penelitian ini adalah penelitian hukum normatif.

\section{PEMBAHASAN}

\section{A. Perlindungan Kebebasan berpendapat Di} Indonesia Dalam Undang Undang ITE

Sekarang ini, kita sedang memasuki era informasi yang berkembang makin kompleks. oleh karena itu untuk mengelolanya kita perlu memanfaatkan teknologi informasi dengan tepat. Semua hal yang kita hadapi saat ini merupakan kemajuan tapih kemajuan tersebut perlu disikapi dengan peraturan yang baik, karena tanpa kita sadari kemajuan yang begitu pesat ini suatu saat dapat mengubah corak kehidupan umat manusia khususnya dalam mendapatkan dan menyampaikan pendapat

Kebebasan berpendapat dimaknai sebagai suatu hak atas kebebasan pribadi yang menuntut pemenuhan dan perlindungannya, serta dijamin dalam konstitusi. Kebebasan berpendapat merupakan suatu indikator bagi suatu Negara akan keberlangsungan demokrasi di negara tersebut serta dapat menggambarkan akan perlindungan dan pengakuan terhadap Hak Asasi Manusia dalam suatu negara. Bila Sebuah Negara ingin dianggap benar-benar demokratis, ia harus siap memberikan perlindungan substansial untuk ide-ide

\footnotetext{
4 Titian Jalan Demokrasi, Harian Kompas dan Gramedia Literary Agents, ( Jakarta 2000 ), hal 35.
}

\footnotetext{
${ }^{1}$ Artikel Skripsi

${ }^{2}$ Mahasiswa pada Fakultas Hukum Unsrat, NIM. 16071101197

${ }^{3}$ Fakultas Hukum Unsrat, Magister IImu Hukum
} 
pengeluaran pendapat media ${ }^{5}$ Kebebasan berpendapat adalah Hak dasar yang dimiliki oleh tiap individu dalam sebuah negara tercantum pada konstitusi nya. Di Indonesia kebebasan untuk berpendapat diatur dalam Pasal 28E ayat (3) Undang-Undang Dasar sebagai berikut: "Setiap orang berhak atas kebebasan berserikat, berkumpul, dan mengeluarkan pendapat. "

Di samping itu, perlu juga dilihat ketentuan dalam Pasal 28F UUD 1945, yang berbunyi: "Setiap orang berhak untuk berkomunikasi dan memperoleh informasi untuk mengembangkan pribadi dan lingkungan sosialnya, serta berhak untuk mencari, memperoleh, memiliki, menyimpan, mengolah, dan menyampaikan informasi dengan menggunakan segala jenis saluran yang tersedia".

Selanjutnya, perihal kemerdekaan berserikat dan berkumpul, mengeluarkan pikiran dengan lisan dan tulisan dan sebagainya ditetapkan dengan undang-undang. Dalam hal ini, yang mendasari seseorang bebas untuk mengeluarkan pendapat dapat dilihat dalam ketentuan Pasal 23 ayat 2 Undang-Undang Nomor 39 Tahun 1999 tentang Hak Asasi Manusia sebagai berikut:

"Setiap orang bebas untuk mempunyai, mengeluarkan dan menyebarluaskan pendapat sesuai hati nuraninya, secara lisan dan atau tulisan melalui media cetak maupun elektronik dengan memperhatikan nilai-nilai agama, kesusilaan, ketertiban, kepentingan umum, dan keutuhan negara."Meskipun demikian, seseorang dalam mengeluarkan pendapatnya harus menghargai hak orang lain, serta tunduk pada hukum yang berlaku.

Hal tersebut sebagaimana disebutkan dalam Pasal 28J ayat (2) UUD 1945 sebagai berikut:

dalam menjalankan hak dan kebebasannya, setiap orang wajib tunduk kepada pembatasan yang ditetapkan oleh undang-undang dengan maksud semata-mata untuk menjamin pengakuan serta penghormatan atas hak dan kebebasan orang lain dan untuk memenuhi tuntutan yang adil sesuai dengan pertimbangan moral, nilai-nilai agama, keamanan, dan ketertiban umum dalam suatu masyarakat

\footnotetext{
${ }^{5}$ Darwin Prinst. Sosialisasi dan Diseminasi Penegakan Hak Asasi Manusia. Bandung : PT. Citra Aditya 2001 Bhakti.hal 56
}

demokratis. ${ }^{6}$ Ketentuan ini mengakomodasi perlindungan kebebasan berpendapat yang dijunjung tinggi dan melindungi semua warga Negara oleh karena pengaturan akan pengakuan dan jaminan kebebasan berpendapat ini diatur dalam konstitusi, maka sudah menjadi kewajiban bahwa segala ketentuan dan peraturan perundang-undangan dibawanya juga harus sesuai dan tidak bertentangan dengannya. $^{7}$

Dengan begitu banyaknya pengaturan tentang perlindungan akan kebebasan menyatakan pendapat yang diatur dalam peraturan perundang-undangan Indonesia, jelaslah sudah bahwa Indonesia termasuk negara yang menjunjung tinggi atas perlindungan dan penghormatan terhadap Hak Asasi Manusia. Hal ini akan tampak berbeda jika dibandingkan dengan ketentuan yang terdapat dalam Pasal 27 ayat (3) UU ITE No. 19 Tahun 2016 tentang perubahan atas Undang Undang no 11 tahun 2008 tentang ITE. Undang Undang ITE pasal 27 ayat 3 dalam penerapannya, pasal ini tidak mencerminkan akan perlindungan kebebasan berpendapat yang dimiliki seseorang, bahkan seolah-olah justru mengekang kebebasan menyatakan pendapat tersebut. Sehingga beberapa pihak mengajukan Judicial Review (Peninjauan Kembali) ke Mahkamah Konstitusi (MK) terkait pasal ini karena dianggap telah mengekang kebebasan berpendapat dan melanggar Hak Asasi Manusia. Namun dalam putusannya NO.50/PUU-VI/2008 MK beranggapan, bahwa norma yang terkandung dalam Undang-Undang ITE Pasal 27 ayat (3) ${ }^{8}$ mengenai penghinaan dan pencemaran nama baik yang diatur di dalam KUHP tidak dapat menjangkau delik penghinaan dan pencemaran nama baik yang dilakukan di dunia cyber.

Mengkaji mengenai ketentuan dalam Pasal 27 ayat (3) tersebut, penulis melakukan penafsiran secara gramatikal atau secara bahasa. Dari ketentuan Pasal 27 ayat (3) yang berbunyi :setiap orang dengan sengaja dan tanpa hak mendistribusikan dan/atau

\footnotetext{
6 Muhamad Idrus. Sosialisasi dan Diseminasi Penegakan Hak Asasi Manusia. Bandung : PT. Citra Aditya Bhakti. 2001 hal 56

7 Darwin Prinst. Sosialisasi dan Diseminasi Penegakan HAM. Bandung : PT. Aditya Bhakti. 200

${ }^{8}$ R. Herlambang Perdana Wiratraman. Jurnal Konstitusi. Vol. 6, No. 1.2009 hal 213
} 
mentransmisikan dan/atau membuat dapat diaksesnya informasi elektronik yang memiliki muatan penghinaan dan/atau pencemaran nama baik,"

Berdasarkan bunyi pasal tersebut di atas dapat diuraikan unsur- unsur pencemaran nama baik sebagai berikut :

a. Setiap Orang

Pasal 1 angka 21 menyatakan bahwa orang yang di maksud dalam UU ITE adalah orang perseorangan baik warga negara Indonesia, warga negara asing, maupun badan hukum. Jadi, orang perseorangan baik warga negara Indonesia maupun warga negara asing dan/atau badan hukum harus memperhatikan UU ITE khususnya pada 27 ayat (3) dalam menyebarkan suatu informasi elektronik agar tidak menimbulkan penghinaan dan/atau pencemaran nama baik. Orang perseorangan tersebut adalah warga negara Indonesia, warga negara asing maupun badan hukum yang terbukti melanggar Pasal 27 ayat (3) diancam dengan pidana jika memenuhi unsur delik.

\section{b. Dengan sengaja}

UU ITE tidak dijelaskan arti kata sengaja, Dalam KUHP sebagai lex generalis dan dari peraturan perundang-undangan pun tidak dijelaskan. Dalam Criminal Wetboek (Kitab Undang-Undang Hukum Pidana) tahun 1980 "Kesengajaan adalah kemauan untuk melakukan atau tidak melakukan perbuatanperbuatan yang dilarang atau diperintahkan oleh Undang-Undang".

c. Tanpa Hak

unsur tanpa hak ini, Mahkamah Konstitusi dalam Putusannya No. 2/PUU-VII/2009 menyatakan:

"Bahwa unsur dengan sengaja dan tanpa hak merupakan satu kesatuan yang dalam tataran penerapan hukum harus dapat dibuktikan oleh penegak hukum. Unsur "dengan sengaja" dan "tanpa hak" berarti pelaku "menghendaki" dan "mengetahui" secara sadar bahwa tindakannya dilakukan tanpa hak. Dengan kata lain, pelaku secara sadar menghendaki dan mengetahui bahwa perbuatan "mendistribusikan" dan/atau "mentransmisikan" dan/atau "membuat dapat diaksesnya informasi elektronik dan/atau dokumen elektronik" adalah memiliki muatan penghinaan dan/atau pencemaran nama baik. Adapun unsur tanpa hak merupakan unsur melawan hukum. Pencantuman unsur tanpa hak dimaksudkan untuk mencegah orang melakukan perbuatan mendistribusikan dan/atau mentransmisikan dan/atau membuat dapat diaksesnya informasi elektronik dan/atau dokumen elektronik yang memiliki muatan penghinaan dan/atau pencemaran nama baik" (Putusan MK No. 2/PUU-VII/2009). ${ }^{9}$

Berdasarkan putusan Mahkamah Konstitusi (MK) tersebut mengatakan bahwa yang dimaksud dengan tanpa hak adalah "perbuatan melawan hukum". maka penulis mencoba membandingkan dengan ketentuan Pasal 30 UU ITE yang dengan tegas menyebutkan secara eksplisit kata-kata "melawan hukum". Jadi terdapat suatu perbedaan penggunaan kata di dalam satu Undang-Undang, tetapi menurut MK mengandung makna yang sama, sehingga terjadi ketidak konsistensi dalam penggunaan kata-kata dalam satu Undang-Undang. Sebab terdapat dua kata dalam satu Undang-Undang, tetapi memiliki makna atau arti yang sama, jelas hal ini sangat membingungkan. unsur ini di takutkan bagaimana jika seorang di dalam melakukan suatu perbuatan pada dasarnya bertentangan dengan undang-undang, padahal dalam hal tersebut ia menggunakan haknya atau terpaksa untuk membela diri, nanti akan terkena juga larangan dari pasal undangundang yang bersangkutan, untuk ketegasan agar seorang apabila menggunakan haknya maka ia tidak "melawan hukum" dan untuk ketegasan bahwa yang diancam hukuman itu hanya orang yang betul-betul melawan hukum saja, maka di dalam pasal yang ini perlu dimuat ketegasan "melawan hukum" sebagai unsur perbuatan terlarang itu. ${ }^{10}$

\section{d. Perbuatan mendistribusikan, mentransmisikan, membuat dapat diaksesnya informasi elektronik}

Undang-Undang Nomor 11 Tahun 2008 tentang Informasi dan Transaksi Elektronik (ITE) tidak menjelaskan definisi dari mendistribusikan, mentransmisikan, dan dapat diaksesnya. Namun, setelah mengalami

\footnotetext{
9 R. Herlambang Perdana Wiratraman.. "Kebebasan Berekspresi, Penelusuran dalam Konstitusi Indonesia". Jurnal Konstitusi. 2009 Vol. 6, No. 1. Hal 201

${ }^{10}$ Lembaga \ Advokasi Masyarakat. Berekspresi di Internet. Jakarta:2013 Hal. 1
} 
perubahan yaitu Undang Undang No. 19 Tahun 2016 tentang ITE, kata mendistribusikan, mentransmisikan dan dapat diakses sudah dikemukakan definisinya masing-masing. Berdasarkan penjelasan Pasal 27 ayat (1) UU RI No. 19 Tahun 2016 tentang perubahan atas UU No. 11 tahun 2008 tentang ITE, yang dimaksud dengan "mendistribusikan" adalah mengirimkan dan/atau menyebarkan informasi elektronik dan atau dokumen elektronik kepada banyak orang atau berbagai pihak melalui sistem elektronik, yang dimaksud dengan "mentransmisikan" adalah mengirimkan informasi elektronik dan/atau dokumen elektronik yang ditujukan kepada satu pihak lain melalui sistem elektronik; dan yang dimaksud dengan "membuat dapat diaksesnya" adalah semua perbuatan lain selain mendistribusikan dan mentransmisikan melalui sistem elektronik yang menyebabkan informasi elektronik dan/atau dokumen elektronik dapat diketahui pihak lain atau publik.

Pasal 1 ayat (1) UU ITE dinyatakan bahwa informasi elektronik adalah satu atau sekumpulan data elektronik, termasuk tetapi tidak terbatas pada tulisan, suara, gambar, peta, rancangan, foto, electronic data interchange (EDI), surat elektronik (electronic mail), telegram, teleks, telecopy, atau sejenisnya, huruf, tanda, angka, kode akses, simbol, atau perforasi yang telah diolah yang memiliki arti atau dapat dipahami oleh orang yang mampu memahaminya. Kemudian dalam ayat 4 dinyatakan bahwa dokumen elektronik adalah setiap informasi elektronik yang dibuat, diteruskan, dikirimkan, diterima, atau disimpan dalam bentuk analog, digital, elektromagnetik, optical, atau sejenisnya, yang dapat dilihat, ditampilkan, dan/atau didengar melalui komputer atau sistem elektronik, termasuk tidak terbatas pada tulisan, suara, gambar, peta, rancangan, foto, atau sejenisnya, huruf, tanda, angka, kode akses, simbol atau perforasi yang memiliki makna atau arti atau dapat dipahami oleh orang yang mampu memahaminya, Dalam Kamus Besar Bahasa Indonesia (KBBI), mendistribusikan berarti menyalurkan (membagikan, mengirikan) kepada beberapa orang atau ke beberapa tempat, mentransmisikan yaitu mengirimkan atau meneruskan pesan dari seseorang (benda) kepada orang lain (benda lain), sedangkan membuat dapat diaksesnya selain hanya memberikan definisi tentang akses yaitu kegiatan melakukan interaksi dengan sistem elektronik yang berdiri sendiri atau dalam jaringan.

e. Informasi Elektronik yang memiliki muatan penghinaan dan atau pencemaran nama baik.

Unsur "penghinaan" dan "pencemaran nama baik" dalam pasal ini masih belum jelas, jika kita melihat dalam penjelasan pasal ini hanya dikatakan cukup jelas. Sehingga perlu ada penafsiran dalam mengartikan konsep penghinaan dan/atau pencemaran nama baik. pengertian terhadap suatu pendapat atau informasi yang memiliki muatan penghinaan dan pencemaran nama baik merupakan suatu pengertian yang sangat subjektif, sehingga parameter dan patokan dalam ketentuan ini masih sangat luas. Batasan seperti apa yang dapat dikatakan bahwa pendapat seseorang tersebut dapat dikatakan menghina atau mencemarkan nama baik seseorang. Terdapat banyak penggolongan dan jenis-jenis dari muatan penghinaan dan pencemaran nama baik, Berdasarkan ketentuan dalam KUHP, apabila dihubungkan dengan objeknya maka terhadap kejahatan ini dapat digolongkan ke dalam beberapa bagian, yaitu :

a. Penghinaan dan pencemaran nama baik terhadap pejabat negara, seperti terhadap Presiden atau Wakil Presiden (Pasal 134 KUHP);

b. Penghinaan terhadap wakil negara asing di Indonesia (Pasal 143 KUHP);

c. Penghinaan terhadap Pemerintah Indonesia (Pasal 154 KUHP);

d. Penghinaan dan pencemaran nama baik terhadap suatu kelompok atau golongan (Pasal 156 KUHP);

e. Penghinaan dan pencemaran nama baik terhadap individu (Pasal 310 KUHP)

f. Penghinaan dan pencemaran nama baik terhadap Pejabat atau Pegawai negeri (Pasal 316 KUHP).

Apabila dihubungkan dengan jenisnya maka penghinaan dapat digolongkan kedalam 5 jenis yaitu :

a. Menista atau Pencemaran Nama Baik secara lisan (Pasal 310 ayat $1 \mathrm{KUHP}$ )

b. Menista atau Pencemaran Nama Baik secara tertulis (Pasal 310 ayat (2) KHUP); 
c. Fitnah (Pasal 311 ayat (1) KUHP)

d. Penghinaan ringan (Pasal 315 KUHP)

e. Pengaduan (Pasal 313 KUHP);

f. Tuduhan (Pasal 310 KUHP)

g. Persangkaan palsu (Pasal 318 ayat (1) KUHP) $)^{11}$

Namun dalam UU ITE, penghinaan dan pencemaran nama baik tersebut tidak lagi dibedakan berdasarkan objek, juga berdasarkan jenisnya, namun hanya disatukan dan juga menyamaratakan seluruh muatan penghinaan dan pencemaran nama baik tersebut dalam satu Pasal 27 ayat (3), Shinta Agustina, pada buku Kebebasan Berekspresi di Indonesia pernyataan yang dikeluarkan orang untuk menghina sangat tergantung kepada pemilihan kata dan cara penyampaian serta perasaan subjektif orang yang dihina terkait dengan rasa harga diri. ${ }^{12}$ bentuk objektif dari menghina adalah bila pernyataan itu menyerang nama baik orang lain, karena akan diukur sejauh mana nama baik seseorang menurun karena penghinaan tersebut. Namun bila terkait dengan "kehormatan" orang lain, maka delik penghinaan menjadi subjektif, terkait dengan rasa yang bersifat subjektif. Oleh karenanya tidak mengherankan, bahwa untuk pembuktian delik penghinaan, dibutuhkan unsur "tujuan untuk menghina" (oogmerk om te beledigen ) Dari unsur unsur Di dalam Pasal 27 ayat 3 UU ITE ini masih ada beberapa proposisi yang belum jelas dan terdapat berapa kelemahan dalam unsurnya yaitu :

- Unsur pencemaran nama baik kabur

Dalam undang undang ITE pasal 27 ayat 3 tidak memuat kejelasan mengenai apa itu pencemaran nama baik, Jadi apa yang pengertian dasarnya penghinaan dan pencemaran nama baik haruslah diuji dengan pengertian yang sama dengan pasal 310 dan 311 kuhp, mencakup pula ketentuanketentuan khusus pasal tersebut seperti: unsur kejahatannya, alasan pembenar nya, maupun doktrin doktrin umum dalam penggunaannya:

Berpotensi melanggar privasi salah satu unsur untuk membuktikan ada atau tidaknya perbuatan penghinaan dan pencemaran nama baik adalah pernyataan

\footnotetext{
${ }^{11}$ Kitab Undang - Unddang Hukum pidana Pasal 310 -318

12 shinta agustina buku Kebebasan Berekspresi di Indonesia - Hukum, Masalah, Gramedia, bandung, (hal. 123),
}

tersebut diucapkan atau ditulis dengan maksud diketahui umum, dan tidak membolehkan adanya pemindanaan terhadap pernyataan pernyataan yang tidak diucapkan atau ditulis di muka umum, tapi karna lemahnya unsur dalam pasal 27 ayat 3 seseorang yang mentransmisikan atau mendistribusikan pernyataan lewat media privat seperti whasup dan messenger juga bisa di pidana.

- Menghilangkan penggolongan dan pencemaran nama baik

Pasal 27 ayat (3) jo Pasal 45 ayat (1) UU ITE sendiri tidak memuat penggolongan penghinaan sehingga menimbulkan kebingungan tentang berapa batas maksimum sanksi pidana penjara atau denda untuk tiap golongan penghinaan (pencemaran, pencemaran tertulis, fitnah, penghinaan ringan, pengaduan fitnah, dan persangkaan palsu). Dan membuat aparat penegak hukum menentukan atau mengestimasi sendiri batas maksimum sanksi pidana penjara dan/atau denda untuk tiap golongan penghinaan, tentunya tidak melampaui batas maksimum sanksi pidana dalam Pasal 45 ayat (1) UU ITE.

- Menghilangkan alasan pembenar dalam tindak pidana penghinaan

Salah satu kelemahan mendasar dari Pasal 27 ayat (3) UU ITE adalah karena mengambil nama bab dalam KUHP menjadi rumusan delik. Akibatnya, tidak ada model penggolongan jenis penghinaan seperti yang terdapat dalam KUHP. Ketiadaan penggolongan ini juga membuat ketiadaan alasan pembenar sebagaimana secara umum dikenal dalam Pasal 310 ayat (3) KUHP.

Oleh karena itu, norma dalam pasal ini dapat dikatakan sebagai norma kabur (vague norm) yang hanya mengatur perbuatan pencemaran nama baik dan/atau penghinaan secara tanpa hak yang dilakukan menggunakan media TIK, namun tidak menjelaskan perbuatan yang dimaksud untuk disiarkan dalam TIK, yang dilarang itu apa, oleh karenanya jika mengacu pada ketentuan Pasal 4 huruf a Undang-Undang ITE yang menyatakan bahwa tujuan dari Undang-Undang ini yaitu untuk mencerdaskan kehidupan bangsa sebagai bagian dari masyarakat informasi dunia. Maka dengan pengaturan yang masih belum terperinci dan masih dapat menimbulkan multitafsir, undang 
undang ini dianggap dapat menghalangi usaha mencerdaskan kehidupan bangsa yang disebutkan dalam tujuan pembentukan Undang-Undang ini.

Selain meninjau secara gramatikal atau secara bahasa atas ketentuan dalam Pasal 27 ayat (3) yang dianggap telah mengekang hak kebebasan berpendapat melalui media internet seseorang tersebut, perlu dilihat pula mengenai pola hubungan dalam ketentuan Pasal 27 ayat (3) tersebut dengan ketentuan perundang undangan yang lain (interpretasi sistematis), khususnya yang berkaitan dengan hak atas kebebasan berpendapat, apakah benar bahwa ketentuan dalam pasal tersebut telah melanggar hak atas kebebasan berpendapat yang dimiliki oleh seseorang dan tidak sesuai dengan ketentuan perundang-undangan yang terkait. Kebebasan berpendapat diakui sebagai "basic human right" dan mendapatkan jaminan perlindungannya dalam Deklarasi Universal Hak Asasi Manusia Tahun 1948. Dalam Pasal 19 "Semua orang mempunyai hak atas kebebasan berfikir dan menyatakan pendapat (the right to freedom of opinion and expression) hak ini mencakup kebebasan untuk mempunyai pendapat tanpa mendapat gangguan (to hold opinions without interference) dan kebebasan untuk mencari, memperoleh dan menyebarkan informasi dan gagasan (to seek, receive and impart information and ideas), lewat media manapun dan tanpa memandang perbatasan negara." Agar kebebasan untuk menyelenggarakan pendapat itu terselenggara dengan baik, maka harus diberikan jaminan kebebasan dan kekebalan atau imunitas, sehingga si pelaku akan terbebas dari rasa takut dikenai "pembalasan" oleh pihak manapun.

Di Indonesia jaminan akan kebebasan tersebut tertuang dalam beberapa Peraturan Perundang-Undangan termasuk Konstitusi UUD 1945. Dalam Pasal 28 sebelum amandemen seperti yang telah disebutkan diatas telah mengakui akan perlindungan dan jaminan kebebasan berpendapat bagi rakyat Indonesia. Setelah amandemen, khususnya amandemen kedua, jaminan akan perlindungan ini semakin dipertegas dalam Pasal 28 huruf E ayat (2) "setiap orang berhak atas kebebasan meyakini kepercayaan, menyatakan pikiran dan sikap, sesuai dengan hati nuraninya," sedang ayat (3) "setiap orang berhak atas kebebasan berserikat, berkumpul, dan mengeluarkan pendapat" dan dalam Pasal 28 huruf F menyatakan "setiap orang berhak untuk berkomunikasi dan memperoleh informasi untuk mengembangkan pribadi dan lingkungan sosialnya, serta berhak untuk mencari, memperoleh, memiliki, menyimpan, mengolah, dan menyampaikan informasi dengan menggunakan segala jenis saluran yang tersedia".

Makna yang terkandung dalam ketentuan tersebut sangat jelas menyatakan bahwa secara konstitusional negara menjamin kebebasan setiap orang memperoleh dan menyampaikan informasi atau berkomunikasi melalui media apapun, karena hak untuk memperoleh dan menyampaikan informasi serta berkomunikasi merupakan hak dan kebebasan bagi semua orang atau warga negara tanpa terkecuali.

Mengacu pada ketentuan yang mengatur tentang Hak Asasi Manusia, yakni UU No. 39 Tahun 1999 tentang HAM seperti yang telah ditegaskan diatas, bahwa jaminan akan kebebasan berpendapat dalam UU ini terdapat dalam Pasal 23 ayat (2). Sebagai negara demokrasi yang menjunjung tinggi perlindungan HAM dengan segala hak-haknya, termasuk hak sipil dan politik warga negaranya, maka Indonesia telah meratifikasi ketentuan Covenant Hak Sipil dan Politik kedalam UndangUndang No. 12 Tahun 2005 sebagaimana yang telah disebutkan diatas, ${ }^{13}$ dikaitkan dengan ketentuan Pasal 27 ayat (3) dalam UndangUndang Informasi dan Transaksi Elektronik, maka dirasa Undang-Undang ITE dapat mengancam kebebasan berpendapat di dalam media internet. Sebab yang diatur di sini adalah sebatas berupa larangan (perbuatan yang tidak boleh dilakukan), sedangkan hak yang dapat dimiliki (dilakukan) oleh pengguna (user) tidak terdapat dalam ketentuan perundangundangan tersebut. Jadi dapat dikatakan bahwa dalam Pasal 27 ayat (3) ini hanya mengatur mengenai kewajiban yang harus dipenuhi oleh seseorang, tidak menyangkut haknya. Sedangkan yang berkaitan dengan hak, yang diatur dalam UU ITE ini hanya mengatur tentang yang berkaitan dengan pembuktian dan syarat-syarat yang harus dipenuhi dalam hal menggunakan Informasi Elektronik atau

\footnotetext{
13 Krisna Harahap. HAM dan Upaya Penegakannya di Indonesia. Bandung: Grafiti, 2003, Hal 66
} 
Data Elektronik, seperti yang terdapat dalam Pasal 7 "setiap Orang yang menyatakan hak, memperkuat hak yang telah ada, atau menolak hak Orang lain berdasarkan adanya Informasi Elektronik dan/atau Data Elektronik harus memastikan bahwa Informasi Elektronik dan/atau Data Elektronik yang ada padanya berasal dari Sistem Elektronik yang memenuhi syarat berdasarkan Peraturan Perundangundangan." Padahal, seperti yang telah diuraikan diatas, bahwa telah banyak ketentuan perundang-undangan yang mengatur dan memberikan jaminan akan kebebasan berpendapat bagi masyarakat, Efektivitas pasal tentunya dapat dilihat dari setidaknya dua sisi, yaitu pengaturan dan penerapan/penegakan (law enforcement). Secara pengaturan, perumusan pasal ini sudah dinilai cukup Sedangkan, dalam aspek penerapan/penegakan pasal yang dimaksud, tentu bergantung pada tiap-tiap kasus yang terjadi atau dengan kata lain penerapan pasal tersebut relatif sulit diukur parameter efektivitasnya.Jika dilihat dari penjelasan di atas dan di kaitkan dengan Pasal 27 ayat 3 UU ITE ,sebenarnya Undang Undang ini memang sangat diperlukan karna memiliki peran penting dalam melindungi transaksi electronic Khususnya di internet, tapi jika dilihat pada penerapannya karena pengaturan dalam pasal ini tidak diatur secara tegas sehingga mengakibatkan multitafsir yang mengancam kebebasan berpendapat, Berdasarkan kajian di atas penulis memberikan alasan mengapa pasal 27 ayat 3 ini mengancam kebebasan berpendapat di Indonesia :

1. pasal tersebut multitafsir, seperti apa yang dimaksud dengan sengaja atau tanpa hak, apa yang di maksud pencemaran nama baik, akibatnya banyak disalahgunakan dan mengakibatkan ancaman bagi kebebasan berpendapat.

2. Tidak memiliki kejelasan pihak yang dihina

3. penggunaan pasal tersebut tidak memiliki satu kepastian hukum karena diterapkan secara beragam, mulai dari proses penyidikan, dakwaan, prosedur penahanan, prosedur pencabutan laporan dan mediasi, termasuk dalam menafsirkan pasal itu sendiri. Penafsiran tersebut terlihat dari pertimbangan hakim dalam menguji unsur-unsur pidana, sehingga praktik pengadilan yang ekstensif

4. tidak diatur mengenai hak-hak yang dapat dimiliki oleh sorang sebagai penggunaan atau penikmat layanan agar dapat melaksanakan hak pribadinya. Yang mengakibatkan setiap orang akan merasa takut menyampaikan pendapatnya karena dalam pasal 27 ayat 3 UU ITE sangat sulit untuk membedakan mana kritik, koreksi, dan tindak pidana pencemaran

Mengingat bahwa internet merupakan sarana berkomunikasi yang tidak mengenal batas, maka demi menciptakan rasa keadilan dan perlindungan akan kebebasan berpendapat, seharusnya diatur mengenai hakhak yang dapat dimiliki oleh sorang sebagai penggunaan atau penikmat layanan agar dapat melaksanakan hak pribadinya tanpa rasa takut. Sebab dengan hanya mengatur mengenai kewajiban yang harus ditaati, maka pengguna akan buta terhadap hak apa saja yang dapat dimilikinya, jadi akan menciptakan perasaan takut dan kekhawatiran dalam menggunakan hak kebebasannya untuk menyampaikan pendapat dan UU ITE ini seakan menjadi hantu bagi pengguna internet dalam mengekspresikan pendapat dan gagasannya. padahal pada dasarnya esensi UU ITE ini tentu jauh lebih besar dari sekadar urusan penghinaan dan pencemaran nama baik, UU ITE harusnya hadir dan memberikan kepastian hukum penyelenggara transaksi electronic yang aman dan bertanggung jawab dan menjadi payung hukum berlakunya cyber law di Indonesia dan di terapkan secara profesional dan bertanggung jawab.

\section{B. Beberapa ragam putusan pengadilan terkait pasal 27 ayat 3 uu no 11 tahun 2008 tentang perubahan atas UU No 19 tahun 2019 tentang ITE}

Segala persoalan rumusan delik yang menyertai dan terjadi di Pasal 27 ayat (3) UU ITE juga tercermin di dalam praktik penerapan dalam pasal ini. Dalam praktiknya Pengadilan pada dasarnya belum menemukan kesamaan dalam penerapan rumusan tersebut dan cenderung menggunakan rumus unsur yang 
telah di atur dalam KUHP. Berikut beberapa putusan pengadilan dan laporan terkait pasal 27 ayat 3 UU ITE:

1. kasus Prita Mulyasari tanggerang

- No putusan : 1269/PID.B/2009/PN.TNG

- Tempat : Pengadilan Negri Tanggerang

- Waktu : 29 November 2009

- Terdakwa : Prita Mulyasari

- Korban : Tindak Pidana Pencemaran Nama

- Pasal yang digunakan: Pasal 27 ayat (3) jo Pasal 45 ayat (1) Undang-undang No. 11 tahun 2008 tentang Informasi dan Transaksi Elektronik atau Pasal 310 ayat (2), atau Pasal 31 ayat (1) KUHP

- Tuntutan: Panjara

- Inti putusan:

- PN mengabulkan eksepsi Penasehat Hukum terdakwa. Menyatakan surat dakwaan JPU

- MA mengadili sendiri perkara tersebut, menghukum terdakwa dengan pidana penjara 6 bulan dengan masa percobaan 1 tahun.

Prita dilaporkan ke Polisi oleh Rumah Sakit Omni Internasional atas tuduhan pencemaran nama baik melalui surat elektronik. Kasus ini bermula dari surat elektronik yang dibuat oleh Prita yang berisi pengalamannya saat dirawat di unit gawat darurat Omni Internasional.

2. Kasus Herrybertus Johan Julius Calame, Singaraja

- No Putusan : 116 / PID / 2011 / PT.DPS

- Tempat : Pengadilan Negri Singaraja Denpasar

- Waktu : 28 mei 2014

- Terdakwa : Herrybertus Johan Julius Calame

- Korban : Antonius Sanjaya Kiabeni

- Pasal yang digunakan: Pasal 27 ayat (3) jo Pasal 45 ayat (1) Undang-undang No. 11 tahun 2008 tentang Informasi dan Transaksi Elektronik atau Pasal 310 ayat (2).

- Tuntutan : Penjara

- Inti putusan:

- Menyatakan Terdakwa. tersebut diatas, tidak terbukti secara sah dan meyakinkan bersalah melakukan tindak pidana yang didakwakan JPU
- Membebaskan Terdakwa tersebut oleh karena itu dari seluruh dakwaan Jaksa/Penuntut Umum tersebut

Johan (Herrybertus Johan Julius Calame), seorang guru SD di Sukadana, Buleleng, Bali, dihukum setelah menulis komentar di FB yang bernada penghinaan. Kasus bermula saat Maria Goreti Delorita menulis status di wall Facebook miliknya pada 6 September 2010. Johan menulis komentar di wall Facebook itu dengan menyebut pihak ketiga yaitu Antonius Sanjaya Kiabeni. Konten komentar yang ditulis Johan adalah menyebut Anton sebagai manusia berkepala dua. Merasa terhina dengan komentar Johan, Anton melaporkan Johan ke Polres Buleleng pada tanggal 21 September 2010.

3. kasus Muhamad Arsyad

- No putusan : 390/Pid.B/ 2014/PN. Mks

- Tempat : Pengadilan Negri Makasar

- Waktu : 1 January 2012

- Terdakwa : Muhammad Arsyad,. SH

- Korban: Khadir Khalid

- Pasal yang digunakan: Pasal 27 ayat (3) jo Pasal 45 ayat (1) Undang-undang No. 11tahun 2008 tentang Informasi dan Transaksi Elektronik atau Pasal 310 ayat 1,atau Pasal 315 KUHP

- Tuntutan : 7 Bulan Penjara

- Inti putusan:

- Menyatakan Terdakwa MUHAMMAD ARSYAD, SH. tersebut diatas, tidak terbukti secara sah dan meyakinkan bersalah melakukan tindak pidana baik dalam dakwaan PERTAMA, dakwaan KEDUA maupun dakwaan KETIGA. Membebaskan Terdakwa MUHAMMAD ARSYAD, SH. tersebut oleh karena itu dari seluruh dakwaan Jaksa/Penuntut Umum tersebut.

Muhammad Arsyad terkena pasal 27 ayat (3) ITE akibat menulis status di BBM miliknya; "No Fear Nurdin Halid Koruptor!!! Jangan pilih adik koruptor!!!", Arsyad dilaporkan ke Polisi oleh Abdul Wahab,anggota DPRD Kota Makassar dari Partai Golkar, yang kabarnya memiliki hubungan kedekatan dengan Nurdin Halid. Kemudian Arsyad ditetapkan sebagai tersangka kasus dugaan pencemaran nama baik Nurdin Halid pada 13 Agustus 2013

4. kasus Ahmad Dhani Prasetyo

- No putusan : 152/PId/2019/PN.SRBY 
- Tempat: Pengadilan Negri Surabaya

- Waktu : 11 juni 2019

- Terakwa : Ahmad Dhani Prasetyo

- Korban: Masyarakat Surabaya

- Pasal yang digunakan: Pasal 27 ayat (3) jo Pasal 45 ayat (1) Undang-undang No 19 tahun 2016tentang perubahan atas Undang Undang No. 1 1tahun 2008 tentang Informasi dan Transaksi Elektronik atau Pasal 310 ayat 1

- Tuntutan : 1 tahun 6 bulan penjara.

- Inti putusan:

- Menyatakan Terdakwa Dhani Ahmad Prasetyo . tersebut diatas terbukti secara sah dan meyakinkan bersalah melakukan tindak pidana pencemaran nama baik Menjatuhkan pidana selama 1 tahun

Kasus ini bermula ketika Dhani membuat vlog yang bermuatan ucapan 'idiot' saat ia berencana menghadiri deklarasi \#2019GantiPresiden di Surabaya, 26 Agustus 2018 silam. Ketika itu, Dhani tertahan di lobi hotel dan tak bisa menghadiri acara yang digelar oleh pendukung gerakan ganti presiden. Dhani, melalui vlognya, menggunakan kata "idiot" saat mengacu ke pihak-pihak yang tidak setuju dengan gerakan ganti presiden. Dhani kemudian dilaporkan oleh aktivis Koalisi Bela NKRI ke Kepolisian Daerah Jawa Timur (Polda Jatim). Pelapor merupakan salah satu elemen yang berdemo menolak deklarasi \#2019GantiPresiden

5. Kasus Muhammad Yusroh Hasibuan

- No putusan : 192/PID/2019/PN.KISRN

- Tempat : Pengadilan Negri kisaran, Sumatra Utara

- Waktu: 192/PID/2019/PN.KISRN

- Terdakwa : Muhammad Yusroh Hasibuan

- Korban : Kapolda Sumut

- Pasal yang digunakan : Pasal 27 ayat (3) jo Pasal 45 ayat (1) Undang-undang No 19 tahun 2016tentang perubahan atas Undang Undang No. 1 1tahun 2008 tentang Informasi dan Transaksi Elektronik atau Pasal 310 ayat 1

- Tuntutan : 1 tahun 6 bulan penjara

- Inti putusan:

- Menyatakan Terdakwa Muhammad Yusroh Hasibuan. tersebut diatas terbukti secara sah dan meyakinkan bersalah melakukan tindak pidana pencemaran nama baik

- Menjatuhkan hukuman kepada terdakwa oleh karena itu dengan pidana penjara selama 9 bulan,"

Kasus ini berawal saat Yusroh mengunggah sebuah foto unjuk rasa di depan Polres Pematangsiantar yang terjadi pada Kamis, 27 September 2019 lewat grup percakapan WhatsApp. Anggota grup bertanya perihal foto yang dikirimkan Yusroh. Selanjutnya, Yusroh menjawab "Siantar Simalungun,GMNI,GMKI,HMI, Himmah BEM dan lain lain. Mengutuk tindakan represif oknum Polri. Copot Kapoldasu". Kapolda Sumatera Utara Irjen, Pol, Agus Andrianto merasa dipermalukan dan direndahkan martabatnya usai membaca screenshot unggahan Yusroh. Selanjutnya, Yusroh ditangkap Polda Sumatera Utara pada 7 November 2018.

Dari beberapa Putusan Pengadilan di atas telah menunjukkan bahwa apa yang diatur dalam Pasal 27 (3) UU ITE, merupakan tindak pidana yang masih memerlukan banyak penafsiran. Dan dalam praktiknya dalam menjatuhkan hukuman terdapat beberapa putusan yang berbeda. Karena dalam menjatuhkan hukuman setiap hakim memiliki penafsiran yang berbeda dalam menguji unsurunsur pidana dalam Undang Undang No 19 tahun 2016 tentang perubahan atas Undang Undang No 11 tahun 2008. sehingga dapat dikatakan dalam hal perlindungan mengenai kebebasan berpendapat belum di atur secara tegas dan masi terlalu luas yang memungkinkan terjadinya multitafsir dalam Undang Undang ini.

\section{PENUTUP}

\section{A. Kesimpulan}

1. Kebebasan berpendapat dalam UndangUndang No. 19 Tahun 2016 tentang perubahan atas undang-undang no 11 tahun 2008 tentang Informasi dan Transaksi Elektronik (ITE) belum di atur dengan baik

2. Pasal 27 Undang-Undang No. 19 Tahun 2016 tentang perubahan atas undangundang no 11 tahun 2008 tentang Informasi dan Transaksi Elektronik (ITE) dapat mengancam kebebasan 
berpendapat karena pasal tersebut multitafsir

\section{B. Saran}

1. Merevisi ketentuan dalam UndangUndang No 19 tahun 2016 tentang perubahan atas Undang Undang No. 11 Tahun 2008 tentang Informasi dan Transaksi Elektronik dengan memperjelas mengenai ketentuan dalam Pasal 27 ayat (3)

2. Memberikan literacy kepada masyarakat tentang pemberlakuan UU ITE ini sehingga masyarakat tidak dipidana karena menyampaikan atau meyalurkan pendapatnya.

\section{Daftar Pustaka}

Agustina, Shibta, Kebebasan Berekspresi Di Indonesia - Hukum, Dinamika, Masalah, dan Tantangannya Gramedia, solo, 2016

Cawindu, Ismail, Bijak Bermedia Sosial, Direktorat Jendral Informasi dan komunikasi Publik Kementrian Komunikasi dan Informatika RI,2013), PT Grafindo, Jakarta, 2013.

Duswara, Dudu, Pengantar Ilmu Hukum, cetakan ke 13 PT Rafika Aditama. Bandung 2009

Harahap, Krisna, HAM Dan Upaya Penegakkannya di Indonesia, Gramedia Literary Agents, Jakarta ,2003.

Hendokngko,Titian, Jalan Demokrasi, Harian 2 Kompas dan Gramedia Literary Agents, Jakarta, 2000.

Habernas, Jurgen, Ruang Publik Dalam Terjemahan Yudah Santoso, PT. Kreasikencana, Yogyakarta, 2007.

Prinst, Darwin, Sosialisasi Dan Deminasi penegahkan Hak Asasi Manusia, Gramedia, Bandung, 2003

Wijayanta, Tata, Asas Kepastian Kukum , Keadilan dan Kemanfaatan, PT Reflika Aditama, Solo, 2009

\section{Sumber Lainya:}

\section{Kamus}

Kamus Filsafat. Lorenz Bagus. Gramedia .Jakarta. 2002

Kamus Besar Bahasah Indonesia, Jakarta, Gramedia Pustaka Utama 2008

Black Law Dictionary, ninth edition, USA, 2009.

\section{Peraturan Perundang-undangan}

Undang-Undang Dasar Negara Republik Indonesia Tahun 1945

Deklarasi Universal Hak Asasi Manusia 1948 Kovenan Hak Sipil Dan Politik 1966.

Undang undang No. 9 Tahun 1998 tentang Kemerdekaan Menyampaikan

Pendapat Di Muka Umum

Undang undnag No. 39 Tahun 1999 tentang Hak Asasi Manusia

Undang undang No. 12 Tahun 2005 tentang Hak Sipil Dan Politik

Undang undang No. 19 Tahun 2016 Tentang Perubahan atas 11 Tahun Undang undang 2008 Tentang Informasi Dan Transaksi Elektronik

\section{Jurnal}

Perwita Anak Banyu, Penegakan HAM, Jurnal Hukum Pro Justitia, Vol 4. No 2 April 2006.

Djalantik, sukawarsini, Etika Kebebasan Beragam,. Jurnal Filsafat, Vol 18 No 3. Hal. 242-243. Juli 2015.

Kusuma, Mulya, Hukum, Dinamika, Masalah, dan Tantangannya Lembaga Studi dan Advokasi Masyarakat (ELSAM), Vol 1 No 2 HAL. 44 2. November 2016.

Herlambang , R, . 2009 Jurnal Konstitusi Kebebasan berekspresi di indonesia.

Vol. 6, No. Hal 67-68. Juli 2017.

Tony Yuri Rahmanto. Jurnal Hak Asasi Manusia. Vol 7 No 1. Hal. 48. Oktober 2018.

\section{Internet}

https://id.safenet.or.id/ Diakses pada 19 januari 2020 jam 16.23 WIB.

https://id. Scholastica Gerintya.or.id/ - 18 Oktober 2018 artikel "Jerat UU ITE Banyak Dipakai oleh Pejabat Negara", Diakses pada 19 januari 2020 jam 16.23 WIB.

https://tirto.id/c7sk, Diakses pada 19 januari 2020 jam 16.23 WIB.

http://icjr.or.id/ Menimbang-Ulang-Pasal-27ayat-3-UU-ITE-dalam-PutusanPengadilan.pdf Diakses pada 19 januari 2020 jam 16.23 WIB. 